\title{
Backyard Agricultural and Farm Activity as an Option of Socioeconomic and Food Improvement in the Rural Towns of the Municipality of Guasave, Sinaloa
}

\author{
Griselda Karina González-Félix ${ }^{1}$, Víctor Manuel-Peinado Guevara ${ }^{2, *}$, Héctor José Peinado-Guevara ${ }^{2, *}$, \\ Aldo Alán Cuadras-Berrelleza ${ }^{2, * \mathbb{D}}$, Jaime Herrera-Barrientos ${ }^{3, *}$, José de Jesús López-López ${ }^{2}$ \\ and Nicolás Guadalupe Zúñiga-Espinoza ${ }^{2} \mathbb{D}$
}

1 Centro Interdisciplinario de Investigación para el Desarrollo Integral Regional, Unidad Sinaloa, Instituto Politécnico Nacional, Blvd. Juan de Dios Bátiz Paredes \#250, Guasave C.P. 81100, Sinaloa, Mexico; grisk_07@hotmail.com

2 Facultad de Ciencias Económicas y Administrativas, Universidad Autónoma de Sinaloa, Boulevard Juan de Dios Bátiz, Guasave C.P. 81049, Sinaloa, Mexico; jesuslope4@gmail.com (J.d.J.L.-L.); nicozu1@uas.edu.mx (N.G.Z.-E.)

3 Centro de Investigación Científica y de Educación Superior de Ensenada, Baja California (CICESE), Carretera Ensenada-Tijuana No. 3918, Zona Playitas, Ensenada C.P. 22860, Baja California, Mexico

check for updates

Citation: González-Félix, G.K.; Guevara, V.M.-P.; Peinado-Guevara, H.J.; Cuadras-Berrelleza, A.A.; Herrera-Barrientos, J.; López-López, J.d.J.; Zúñiga-Espinoza, N.G. Backyard Agricultural and Farm Activity as an Option of

Socioeconomic and Food Improvement in the Rural Towns of the Municipality of Guasave, Sinaloa. Sustainability 2021, 13, 3606. https:// doi.org/10.3390/su13073606

Academic Editor:

Francisco Entrena-Duran

Received: 23 February 2021

Accepted: 19 March 2021

Published: 24 March 2021

Publisher's Note: MDPI stays neutral with regard to jurisdictional claims in published maps and institutional affiliations.

Copyright: (c) 2021 by the authors. Licensee MDPI, Basel, Switzerland. This article is an open access article distributed under the terms and conditions of the Creative Commons Attribution (CC BY) license (https:// creativecommons.org/licenses/by/ $4.0 /)$.
* Correspondence: v_peinadootmail.com (V.M.-P.G.); hpeinado75@hotmail.com (H.J.P.-G.); aalan@uas.edu.mx (A.A.C.-B.); jherrera@cicese.mx (J.H.-B.); Tel.: +52-687-107-3298 (V.M.-P.G.); +52-687-122-1862 (H.J.P.-G.); +52-687-109-0110 (A.A.C.-B.); +52-646-126-0074 (J.H.-B.)

\begin{abstract}
The analysis of the economic problems of the population in Latin America in the face of unemployment and inflation, which have become permanent in these economies, gives rise to the generation of proposals for the solution of social deficiencies, as well as sustainable factors that govern the behavior and culture of production today. The objective was to establish the importance and contribution that backyard activities can have to reach positive socioeconomic and nutritional levels in the rural area of the municipality of Guasave, Sinaloa, Mexico. An exploratory analysis was carried out, to diagnose the problem, applying interviews to describe the socioeconomic and backyard perspectives, finding that more than $70 \%$ of those consulted carry out this activity in relation to livestock and/or agricultural dynamics. Two variables with positive economic effects stand out: self-consumption and commercialization, which are relevant socioeconomic aspects in the relationship between production and family economy, as well as the promotion of self-employment and preservation of family traditions in rural communities.
\end{abstract}

Keywords: rurality; agro-ecology; socioeconomics; backyard activity

\section{Introduction}

The objective of this research was to establish the importance and contribution that the backyard activity can have to reach socioeconomic levels in the rural area of the municipality of Guasave, Sinaloa, Mexico, from the relationship that arises from the inclusion of the activity in the search for economic and social welfare, promotion of the sense of belonging to family customs and traditions, and environmental security.

Global economic conditions have shown the backwardness of historically marginalized sectors; in this context, the population must wake up and invent opportunities to obtain basic resources, while governments promote, from their administrative and public finance organization, the adequate support to the different ways of doing economy.

In rural Latin America, activities are carried out in vegetable gardens and/or family farms, located in the backyards of homes, each with different physical characteristics in terms of size, structure and function, known as backyard activities. The Food and Agriculture Organization of the United Nations [1] considers these types of techniques 
among families to be a rural production system that, in addition to generating economic income, combines different types of functions, such as food production and cultivation, as well as fruit trees, fodder, medicinal plants and animal husbandry; it conserves natural resources and biodiversity, so there is little or no use of fertilizers, pesticides, hormones or antibiotics.

These activities complement a series of physical, economic and social activities, and their main objective is to reduce food deficiencies in rural areas; one of the main advantages is the training of family members in the acquisition of responsibilities, skills and knowledge [2].

The initial part presents a definition of the general conditions in terms of preliminary diagnosis and the procedures and structures in which the rural system is established, contextualized in domestic production, as well as the basic definitions and schemes that explain the phenomenon, within the context of interest.

The methodological part combines qualitative and quantitative resources for obtaining and analyzing data that can establish the relationship of that domestic production, with the most ambitious forms of efficiency, in that sense, linking the forms of production, types, levels and resources used, in addition to the economic condition prevailing in the environment.

The results obtained can generate expectations of deep study on the subject, in order to transcend to the incorporation of the public sector in the take-off projects of collective, individual and environmentally friendly productive alternatives.

In 2016, we started to research how backyard activities are developed in rural communities in Guasave and whether they are sustainable. This led us to design an instrument that would allow us to visit the communities and obtain direct information from the main actors, that is, the families that carry out these activities. From the sampled universe, we obtained a sample size that represents the universe with a 95\% confidence level. An opinion survey was applied to this sample size in 2016, as it is an instrument that allows for interacting and obtaining information directly from the population of interest.

\section{Theoretical Considerations}

\subsection{Backyard Activities in the Context of the New Rurality}

The world's population demands food for subsistence. In the poorest regions, this demand is hardly met, due to lack of income, so backyard or small-scale urban agriculture is a source that generates healthy food and income for the family [3]. In addition to the aforementioned attributes, it also has ecological and therapeutic effects (especially in older adults) for health, especially in countries with better incomes [4,5]. As a healthy foodproducing source, it is used in West Africa [6]. In Ghana, in addition to producing food, it improves household income and generates expenditure savings [7]. In Europe, small farms contribute to food and nutritional, as well as socioeconomic, security [8]. In times of economic hardship for the world, such as the one we are going through because of Covid19, backyard food production is an alternative to produce healthy food [9]. In the backyard, in addition to agricultural activity, there is animal husbandry [10], involving protein producers, such as poultry, pigs and cattle [11,12]. Backyard activities also contribute to the improvement of environmental conditions and the reduction of pesticides [13]. Therefore, backyard activities, in addition to constituting a source of food, offer therapeutic well-being, environmental improvement, increased economic income and the development of a more harmonious family relationship.

Due to the diversity of functions that backyard activities have, in this work, we understand that they are those that are carried out on the properties of households in the rural communities of Guasave, with the participation of the family in the cultivation of vegetable species or animal husbandry, in an artisanal way, for food subsistence and improvement of family income through the sale of part of what is produced and savings for self-consumption. Thus, backyard activities can be perceived as an agro-ecosystem that is distinguished by a segment of nature and that has a limit, which should be conceived 
as an ecosystem where the ends are designated by the producer himself [14,15]; it works as a key tool to improve food security and reduce poverty indexes; in addition, it has been suggested as a strategy to reduce rural poverty and integrate small agriculture into market economies [16].

The impact of backyard activities has a direct focus on the families that carry them out; it can be due to the labor force, the tasks or the responsibilities assigned to each family member; and it seeks to compensate for problems related to food security, nutrition, health and economic security $[17,18]$.

The backyard, in a traditional way, is a space of activity that supports household nutrition through the production of food under artisanal techniques, using basic tools of the field, without the use of modern technologies in the production processes, where the economic benefits are obtained from self-consumption and/or commercialization. For this reason, it can be said that the backyard, as such, is a food reserve adjacent to homes and whose main objective is to manifest the identity, the culture of families and their relationship with nature and the environment, for which, in the backyard, families practice social, biological and agronomic activities, constituting it as an economic unit of consumption [19].

According to the Mexican government [20], backyard activities promote food selfsufficiency, in addition to other benefits for those who participate in these activities and society in general:

- Economic savings.

- Greater social coexistence and integration.

- Food security is promoted.

- $\quad$ Promotion of a culture of environmental protection.

- Development of productive and sustainable projects.

Backyard production can become, in the coming years, a fundamental safeguard for Mexico to achieve food sovereignty; it is defined as food sovereignty, by supporting the rights of people in rural areas to feed themselves, but above all, to generate their own food ahead of commercial, national or international interests [21,22].

One of the approaches to rural analysis, in terms of economic theory, is the productive vision, where the main factor studied is related to the increase in production, industrialization and trade of goods, elements that, in recent decades, do not clearly explain the social development of nations and their different regions, a situation that is no different when conducting studies of local scope, such as the present research. On the other hand, there is rural development, with a territorial approach, which "implies the dynamic and self-sustained transformation of the rural milieu, through the generation and increase of the productive capacities of the various economic agents" [23].

The social, economic and cultural transformations in rural areas during the last decades allow us to reflect on the new functions of the countryside and rural life; its relevance is based on the new challenges in rural areas, conceived as the new rurality, which is manifested as the process of transformation of rural areas [24].

The new rurality, from an unofficial approach, offers concrete elements that help to understand the basic productive and social processes, to consolidate an ecological economy, part of a globalizing environment that affects economic activities, institutions, culture and historical heritage $[25,26]$. It is perceived as multifunctional and multicultural, a conceptualization that starts from the boundary between the rural and the urban [27]. New agricultural activities are also being developed in this space, oriented towards special market niches. This orients rural populations towards economic pluriactivity that incorporates the occupational employment of the members that make up a rural community for the development of economic activities and income generation [28]. Agricultural practices have a determining role at all levels where these noble activities are manifested; the agroecological approach contributes to the achievement of objectives aligned with sustainable development, as well as with economic ones, and in particular, in the rural environment. According to Ortega and Rivera [29], in recent years, the commercialization of agri-foods 
has suffered crises of various kinds, especially those of a social, ecological and sanitary nature, which have led to problems of food security and poverty reduction.

Since 1982, Mexico's developmental economic model was replaced by the neoliberal model, characterized by the promotion of structural adjustment programs, and consequently agricultural policy was restructured, to adapt it to the new demands of the model, resulting in less state intervention in agricultural and rural development [30].

It should be noted that agricultural production is still booming, continuing with the implementation of technological packages that are less environmentally friendly, so that the restructuring referred to by the previous authors did not reduce ecological or environmental problems in the productive activities of the rural sector.

López [31] points out that the current neoliberal model seeks to promote consumption of the countryside at material levels, through intensive, productive and highly technological production systems, characteristic of the new rurality, which is leading to the capitalization of the countryside and the adaptation of the external, in terms of forms of production, to traditional and local markets.

Chayanov's theory of peasantry and the productive exploitation of family units points out a series of elements that must be present in the domestic units: the family and noncontracted labor force, the family organization and size, and the location of the domestic production unit [32]; in addition, the main objective of the peasant domestic production unit is the satisfaction of consumption needs, and not profit; however, it highlights the production and transfer of surpluses generated through the domestic units [33].

In this way, we understand that the certainty of human nutrition depends not only on the perspective of providing healthy food, but also on the search for food self-sufficiency, that is, when there is the capacity to satisfy food needs through local production [34]. For them, backyard activities play an important role for the rural population, even in the new contexts represented by the new rurality in Mexico and the public policy environment.

\subsection{Backyard Activities, Environment and Food Security in Mexico}

In order to achieve sustainable development, it is necessary to understand how the natural systems that surround us function and how they provide inputs to society, under an environmental and conservation analysis based on socioeconomic activity. If we start from an adaptive systems approach, this will allow disciplinary analysis of environmental, social and economic type, as well as multidisciplinary integration [35].

Roulet [36] points out that agricultural system can be analyzed holistically, considering the elements that interact with each other and with the context in which they are found. On the other hand, the co-evolutionary vision proposes that societies interact with their local environment, enriching or degrading it according to their knowledge and appreciation of it [35]. According to Food and Agriculture Organization (FAO) data [37], around five million people depend on this type of activities and mode of agricultural production in Mexico, and the main actors are the indigenous and local peoples, pointing out that the basis of these initiatives is family agriculture and livestock farming, which is considered essential to face the economic and food crisis.

In this sense, Alianza Salud [38] mentions that the Mexican government should promote a production model aligned with sustainability through programs related to production, which helps to achieve the Sustainable Development Goals of the UN 2030 agenda.

It is important to note that, to achieve the above, it is proposed that production processes should start with the use of organic fertilizers in backyard farming activities, avoiding the use of pesticides and chemical fertilizers. Meanwhile, for those who carry out backyard livestock activities, the practices should be in accordance with the sustainable management of available resources. Thus, those who promote sustainable backyard practices "have the challenge of becoming innovators and creators of new models, collaborative processes, methods and research tools, basic and applied, in areas such as agriculture, forestry, livestock and the use of natural resources" [39]. 
To meet this challenge, it is necessary to combine their activities under a multidisciplinary approach, constantly resorting to form working teams with specialists from other areas of knowledge, to promote, together, processes of environmental improvement with social benefits, seeking to generate solutions to the phenomenon of lack of food security.

According to Alvarez, Mancilla and Cortes [40], the main cause of food insecurity in the world does not stem directly from the availability of food, but from insufficient income to acquire or produce it, which is related to social exclusion. Based on the above and the objective stated in the introductory part of this work, priority is given to the search for the relationship between backyard activities and the results obtained by families in rural areas in the study zone, characterized by agricultural and/or livestock practices and their benefits.

Taking into account the dimensions of food security, in a proposal by FAO, cited in Martínez [41], at least five characteristics should be considered for food availability (see Table 1).

Table 1. Characteristics that food production must possess the following characteristics.

\begin{tabular}{|c|c|}
\hline Characteristics & Description \\
\hline Enough & $\begin{array}{c}\text { With adequate levels of energy content from food for each } \\
\text { inhabitant of a region. }\end{array}$ \\
\hline Stable & Constant levels of food availability. \\
\hline Autonomous & $\begin{array}{l}\text { It refers to food self-sufficiency; it is considered as the indicated } \\
\text { level of the capacity to satisfy the effective demand and to supply } \\
\text { food to the population in sufficient quantity without depending } \\
\text { on the external supply. }\end{array}$ \\
\hline Sustainable & $\begin{array}{l}\text { Agri-food systems must propose techniques for the protection of } \\
\text { natural resources, without compromising the food security of } \\
\text { future generations. }\end{array}$ \\
\hline Harmless & $\begin{array}{l}\text { Where the health of individuals is not compromised by the } \\
\text { consumption of food. }\end{array}$ \\
\hline
\end{tabular}

Source: own elaboration, with data from Martínez [1].

\section{Materials and Methods}

In the present study, different methodological resources (surveys and semi-structured interviews) were addressed, in which the subjective and objective aspects of the information are considered; therefore, it is designed under a mixed approach, used to describe an activity that consists of reconciling several points of view on a particular aspect, in order to know the intended reality. Thus, the idea is that, when a hypothesis or result survives the confrontation of different methods, it has a higher degree of validity than if it is tested by a single one [42].

Based on the advantages of a research design with a mixed approach [43], in which a broader perspective of the phenomenon under study can be obtained and where the combination of methods allows for more solid scientific inferences to be reached, it is considered that, in order to address the problems present in rural communities, where poverty and few development opportunities are more frequent among the inhabitants, backyard activities represent an alternative that should be promoted as one of the ways to achieve food self-sufficiency and improve the economic conditions of these sectors. To this end, the methodological approach to the phenomenon studied requires a broad analysis, in which different research resources are explored, to allow a greater depth in the results. The opinion survey was conducted to diagnose the benefits of backyard farming in the rural communities of Guasave, Sinaloa. It is an appropriate way to learn directly from the stakeholders what this activity represents for their health, income and family savings.

\subsection{Study Area}

The municipality of Guasave is geographically located at coordinates $25^{\circ} 33^{\prime} 55^{\prime \prime}$ north latitude and $108^{\circ} 28^{\prime} 18^{\prime \prime}$ west longitude (Figure 1), with an altitude of $21 \mathrm{~m}$ a.s.l.; it has a 
physiography of Pacific coastal plain with gentle slope in the approximate order of $1 \mathrm{~m}$ per kilometer. It presents 3 types of climates: dry, very warm and warm; semi-dry, very warm and warm; and dry, very warm and warm; and the average annual temperature of $24.8^{\circ}$, according to data from the Jaina meteorological station, is the closest for the series of the years 1986 to 2015 [44].

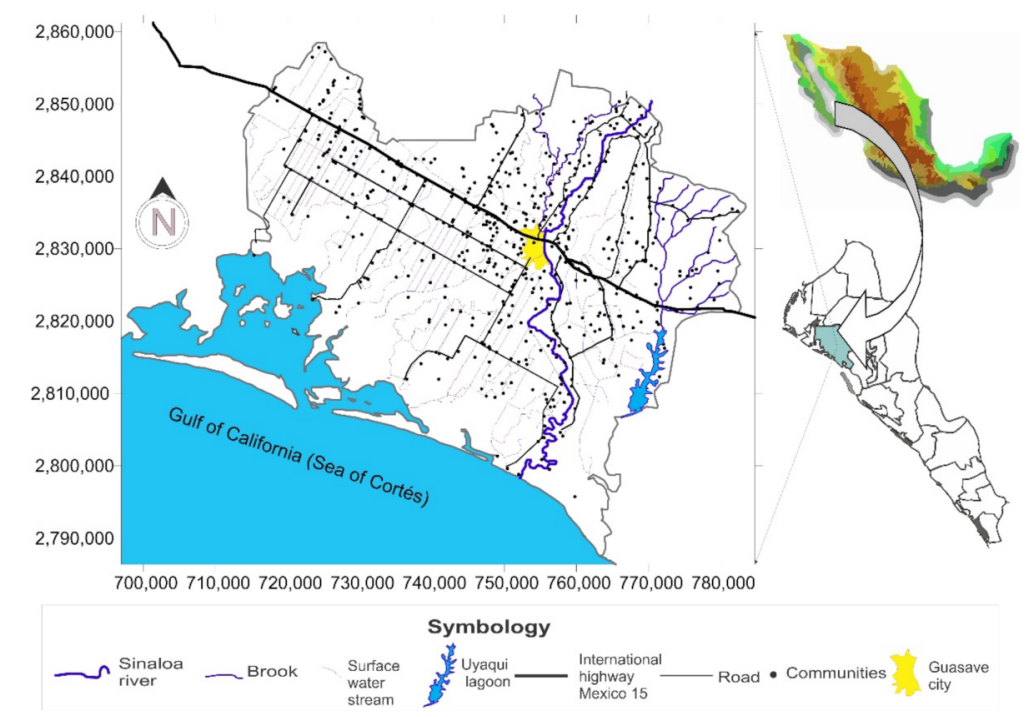

Figure 1. Location of the study area. Source: own elaboration, with data obtained from References $[45,46]$.

Castañozem or Chesnut soils predominate, prototypical of dry climate regions with moisture deficiency; one of the main characteristics of this edaphological unit is its richness in organic material and a chestnut brown hue on the surface [47]. It should be noted that the depth of the static level varies from 1 to $19 \mathrm{~m}$, gradually increasing from the coastal zone as one ascends topographically [48].

The Sinaloa River flows through the municipality of Guasave, as do the Ocoroni and Cabrera streams. There is an extensive system of irrigation canals to satisfy the water demand for agricultural activity. Agriculture occupies $70 \%$ of the municipal area, with more than 346,441 hectares, of which 181,542 is irrigated, 27,691 is for livestock, 12,570 is for forestry and 124,638 is for other uses [49].

Because agriculture is the main economic activity in the municipality of Guasave, most of the population is located in communities of the ejido type, in which, according to Article 93 of the Federal Agrarian Reform Law, it is established that the owner of a parcel of land for agricultural use has the right to receive free of charge, as family patrimony, a plot of land for urbanization to establish his home without exceeding 2500 square meters. Therefore, the assigned spaces have allowed them to build their house and have a patio where they can carry out backyard activities. It is important to point out that many families have wells on their properties that allow them to obtain water directly from the aquifer for their activities, taking advantage of the depth of the static level, which, in most cases, does not exceed $20 \mathrm{~m}$.

\subsection{Population and Sample}

The study was conducted in the rural localities of the municipality of Guasave, Sinaloa, which has a total population of 295,353 inhabitants [50] and 77,005 households and private dwellings [51], of which 46,824 households belong to the rural areas of the municipality [52].

The research strategy used to address the problem is an exploratory study to generate a preliminary diagnosis, describing the problem that has been scarcely addressed [39] and, specifically, backyard activities and their benefits can be identified. 
Based on Malhotra [53], a pilot test was carried out with the purpose of reducing the potential problems within the sample and, thus, determining the incidence in a more accurate way, due to the diversity of factors taken into account, such as livestock or horticultural activity, and for self-consumption and/or commercialization, where an incidence of $90 \%$ of families in the rural sector of Guasave who carry out backyard activities was found.

To determine the sample size, the formula proposed by Torres, Paz and Salazar [54] was used.

To determine the sample size, the formula proposed by Reference [54] was used:

$$
n=\frac{Z^{2} P Q N}{D^{2}(N-1)+Z^{2} P Q}
$$

where $N=$ population size (46,824 homes), $Z=$ confidence level $95 \%(Z=1.96), P=$ probability of success $(90 \%), Q=$ probability of failure $(10 \%$ from the results of the pilot test) and $D=$ precision $(5 \%)$.

Substituting values:

$$
n=\frac{1.96^{2}(0.90)(0.10)(46824)}{(0.05)^{2}(46824-1)+\left(1.96^{2}\right)(0.90)(0.10)}
$$

throwing a result of the following:

$$
n=137.86
$$

Surveys were applied to 138 participating households in the municipality of Guasave, to learn about the development of the backyard economic activity.

One of the aspects to study was the relationship of backyard activities with socioeconomic and agro-ecological activities in the search for sustainable development; for this, the definitions and studies of the authors [55] are considered, based on the concepts of production value of backyard products, sales value, bartering and gift of backyard products, and value of family food consumption. As a first step, the study variables that allowed us to determine the relationship between socioeconomic and backyard activities are identified

\begin{tabular}{|c|c|}
\hline Categories & Indicators \\
\hline Socioeconomic study & $\begin{array}{l}\text { Added and differentiating values } \\
\text { Technology and entertainment } \\
\text { Practical infrastructure } \\
\text { Health infrastructure } \\
\text { Basic infrastructure } \\
\text { Human capital }\end{array}$ \\
\hline Family spending & $\begin{array}{c}\text { House cleaning and care } \\
\text { Personal care } \\
\text { Education, culture and recreation } \\
\text { Communications and services for vehicles } \\
\text { Housing and conservation services } \\
\text { Last paid receipt }\end{array}$ \\
\hline Respondent profile for socioeconomic study & $\begin{array}{c}\text { Age } \\
\text { Sex } \\
\text { Marital status } \\
\text { Occupation }\end{array}$ \\
\hline
\end{tabular}
and are described in Tables 2 and 3.

Table 2. Dimensions of the food-safety variable.

Source: self-made. 
Table 3. Backyard activities variable dimensions.

\begin{tabular}{cc}
\hline Categories & Indicators \\
\hline Livestock backyard activities & $\begin{array}{c}\text { Type of animals that are raised } \\
\text { Purpose of activities } \\
\text { Production accounting }\end{array}$ \\
\hline Agricultural backyard activities & $\begin{array}{c}\text { Type of plants in your home } \\
\text { Purpose of activities } \\
\text { Production accounting }\end{array}$ \\
\hline Work force & Time they spend \\
\hline Livestock backyard activities & Family members involved \\
\hline
\end{tabular}

Source: self-made.

Based on the results of the survey, in terms of the dimensions of the food-security variable, it is possible to know the socioeconomic levels that represent the interpretation of different family traits and characteristics, whose social dimension depends largely on factors such as the education of the head of household, housing conditions and characteristics, and economic income, among others [56]. In Mexico there is the Mexican Association of Market Research and Public Opinion Agencies (AMAI), which works on the location of the different socioeconomic levels that exist in the country (see Table 4), as a hierarchical structure based on the accumulation of economic and social capital, which, based on these six dimensions, measures the possessions and capacity of the household [57].

Table 4. Market Research and Public Opinion Agencies (AMAI) socioeconomic levels.

\begin{tabular}{|c|c|}
\hline Level & Characteristics \\
\hline Level E & $\begin{array}{l}\text { This is the segment with the lowest quality of life or well-being. It } \\
\text { lacks all the satisfying goods and services. }\end{array}$ \\
\hline Level D & $\begin{array}{c}\text { It is the second segment with the lowest quality of life. It is } \\
\text { characterized by having reached a property, but lacks various } \\
\text { services and satisfactory. }\end{array}$ \\
\hline Level D+ & $\begin{array}{c}\text { This segment has the minimal sanitary infrastructure of your } \\
\text { home covered. }\end{array}$ \\
\hline Level C & $\begin{array}{c}\text { This segment is characterized by having reached a practical level } \\
\text { of life and with certain comforts. It has a basic infrastructure in } \\
\text { entertainment and technology. }\end{array}$ \\
\hline Level C+ & $\begin{array}{l}\text { It is the second group with the highest standard of living in the } \\
\text { country. It has the quality of life needs covered; however, it has } \\
\text { certain limitations to invest and save for the future. }\end{array}$ \\
\hline Level A/B & $\begin{array}{l}\text { It is the segment with the highest standard of living in the } \\
\text { country. This segment has all well-being needs covered and is the } \\
\text { only level that has the resources to invest and plan for the future. }\end{array}$ \\
\hline
\end{tabular}

Source: own elaboration from Lopez (2008).

Salazar [55] affirms that backyard agriculture may become, in the coming years, a fundamental refuge for Mexico to achieve its own food sovereignty, as a measure in the face of the recent food shortages perceived in international scenarios.

Regarding the analysis of the results of the variables contained in the instrument in relation to the development of backyard activities, this section characterizes them according to the regional context, in addition to the use or destination of the production and the quantification of the income of those people who practice them for commercial purposes. The relationship of both dimensions allows us to discuss the importance of these activities in rural areas and the contributions generated in the search for food security. 


\section{Results}

The study was conducted in the rural localities of the municipality of Guasave, Sinaloa, which has a total population of 295,353 inhabitants [58] and 77,005 households and private dwellings [51], of which 46,824 households belong to the rural areas of the municipality [46].

The research strategy used to address the problem is an exploratory study to generate a preliminary diagnosis, describing the problem that has been scarcely addressed [59] and, specifically, backyard activities and their benefits can be identified.

Based on Malhotra [53], a pilot test was carried out, with the purpose of reducing the potential problems within the sample and, thus, determining the incidence in a more accurate way, due to the diversity of factors taken into account, such as livestock or horticultural activity, and, for self-consumption and/or commercialization, where an incidence of $90 \%$ of families in the rural sector of Guasave who carry out backyard activities was found.

The instrument was applied to collect information from families in different rural localities of the municipality of Guasave that practice backyard agricultural or livestock activities, in addition to a socioeconomic study of family spending. Different characteristics were found out, such as the importance and dedication that the families give to this type of work and the way in which it influences the economy.

In terms of the profile of those surveyed, 35.5\% are between 46 and 60 years of age, $50.7 \%$ are female and $68.8 \%$ are married (see Figure 2 ).

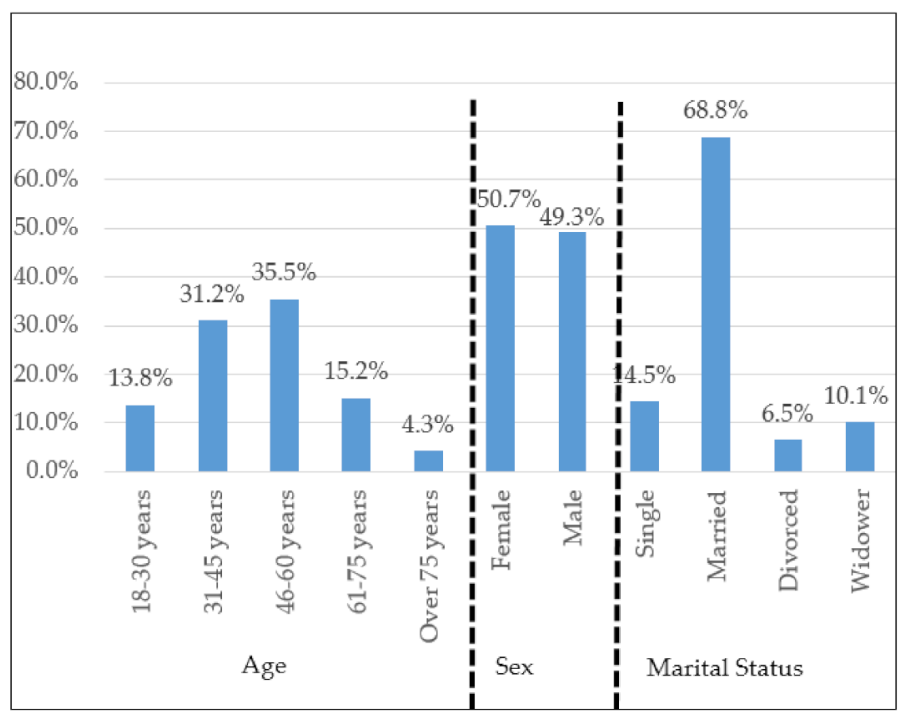

Figure 2. Respondents' profile. Source: own elaboration with data obtained from applied surveys.

In the distribution of backyard activities, they are structured as follows: $50 \%$ indicate that they carry out livestock and agricultural activities, 25\% focus solely on livestock activities and $25 \%$ on agricultural activities. Regarding livestock activities, the answers were multiple choice, because animal breeding, in many cases, comprises more than one species, with each one being a category independent of the others. The most important is the raising and fattening of poultry and pigs, with $44.7 \%$ and $36.9 \%$, respectively, arguing that raising these animals is more economical and accessible for low-income people, as compared to raising animals such as cattle or horses (see Figure 3). 


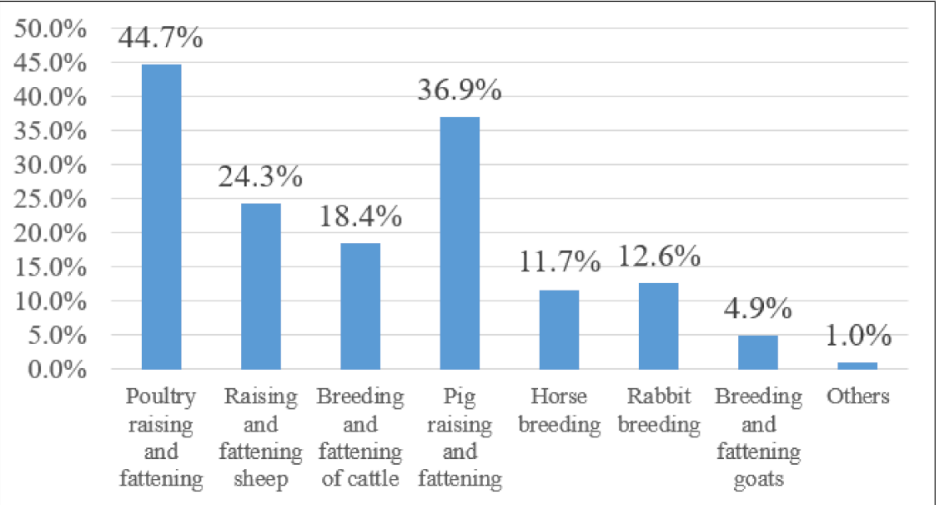

Figure 3. Respondents who answered positively to the practice of livestock activities by species. Source: own elaboration with data obtained from applied surveys.

In socioeconomic terms (self-consumption and sale) in backyard activities oriented to agriculture, the answers were multiple choice because the spaces within the site allow people to have different crops of different species; in this way, each species is a category independent of the others. The cultivation of vegetables and small family gardens stand out. The crops with the greatest presence among the population are pumpkin, especially in the rainy season, due to its favoring of humid climates with $27.3 \%$, and tomato with $22.2 \%$, since it represents one of the most consumed vegetables in the region. Meanwhile, the most typical fruit trees are mango, guava, plum and orange, with an incidence of 50.5\%, 35.4\% and $34.3 \%$, respectively; all together, these are important foods for the diet of families for their high nutritional values (see Figures 4 and 5).

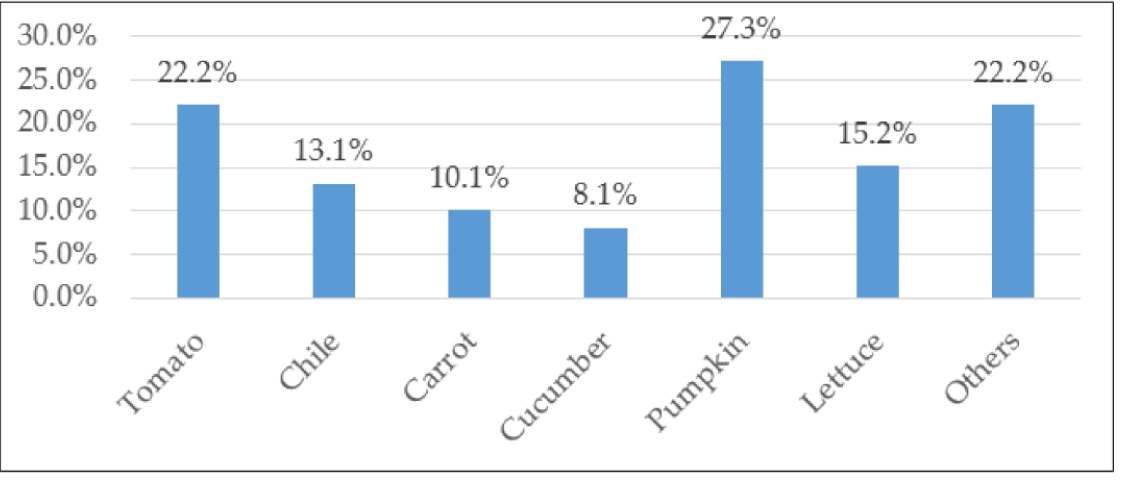

Figure 4. Respondents who answered positively to the practice of horticultural crops by species. Source: own elaboration with data obtained from applied surveys.

In the destination of production, the economic importance of backyard activities is reflected; for those that are destined for self-consumption and those who opt for a mixed use, consumption and commercialization in livestock and agricultural activities stand out (see Figure 6). An important factor to consider in the research is that most of the families that carry out this activity for self-consumption agreed on the advantages of having their own food source at home, which is reflected, in a positive way, in their basic food basket. 


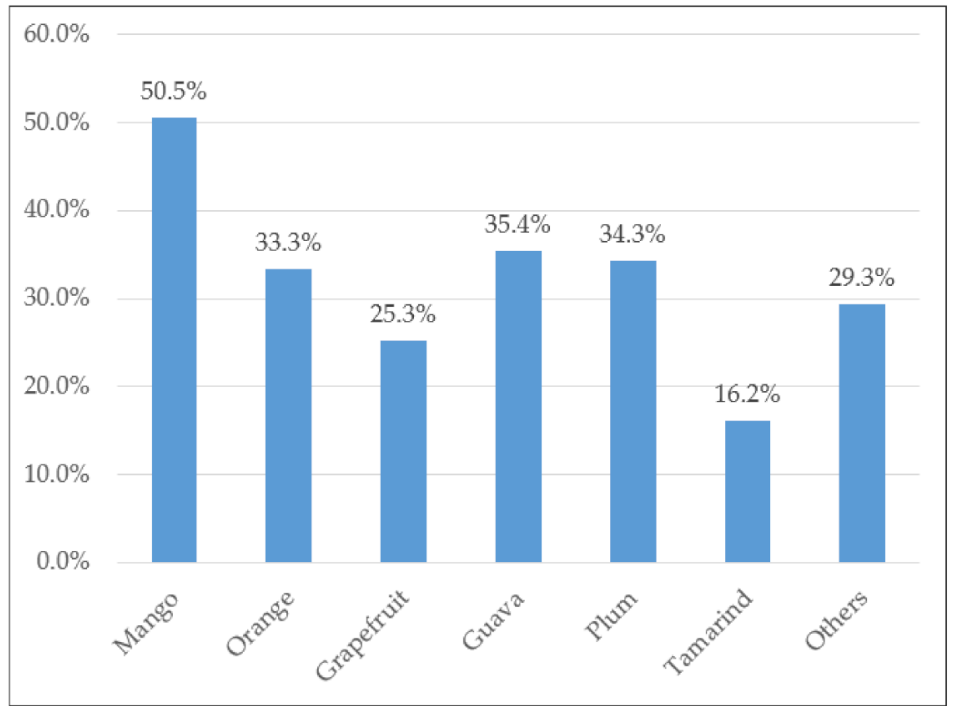

Figure 5. Respondents who answered positively to the planting of orchards by species. Source: own elaboration with data obtained from applied surveys.

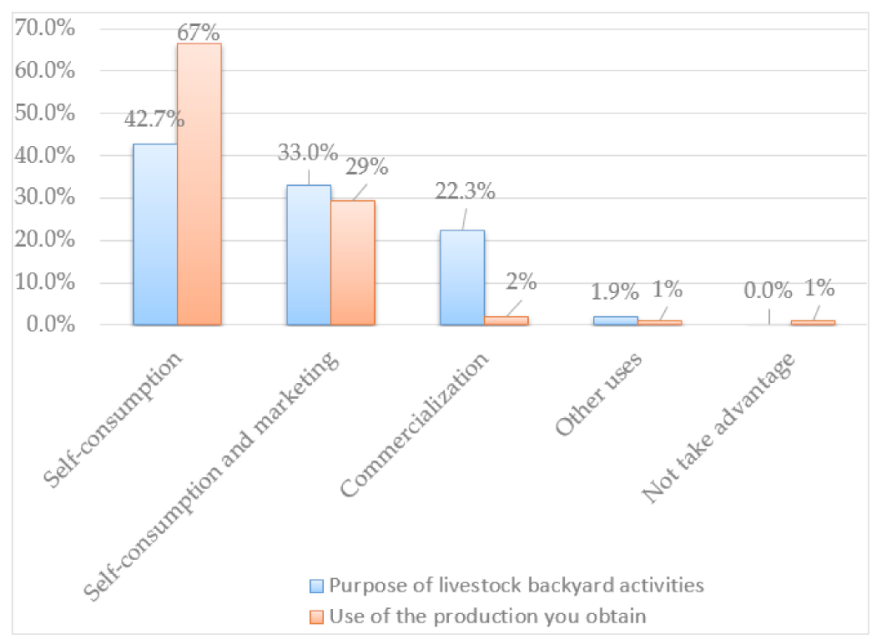

Figure 6. Use of backyard livestock and agricultural activities. Source: own elaboration with data obtained from applied surveys.

However, since it is a very common practice in rural communities, most of them only consider the benefits of self-consumption, but those who use the production for commercialization point out important economic incomes that contribute to the strengthening of the family economy.

One of the focal points of the collection of information in this research is the economic income received from backyard activities and the destination of the resources obtained from commercialization. When asked about the accounting of income, it was observed that $25 \%$ of those who practice backyard livestock activities account for their income, while $10 \%$ of those who focus their production on agricultural activities keep accounting records.

The economic analysis of the contributions of backyard activities was carried out based on how they contribute to family expenses among those who use their production for commercialization. For those who direct their production to livestock activities, the average income represented 1.6 times the minimum wage in force for the year 2016 in Mexico; for those who are dedicated to planting and harvesting food at home, the economic income from sales of vegetables and backyard garden production represented 0.91 times the minimum wage in this same period. Compared to the average current income for 
workers in rural communities, according to INEGI data [60], this represented $83 \%$ and $45 \%$, respectively, for livestock and agricultural activities, considering an $8 \mathrm{~h}$ workday (see Figure 7).

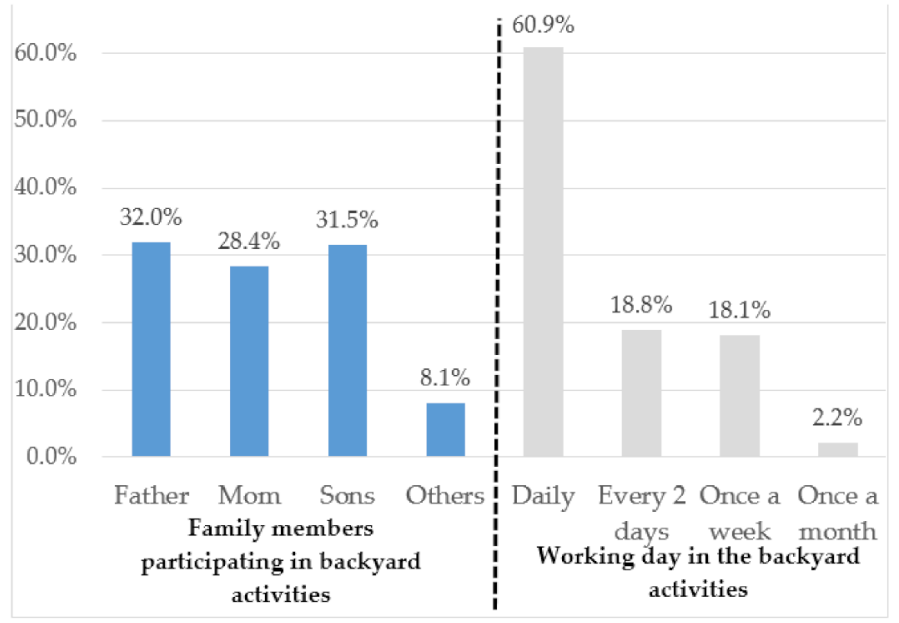

Figure 7. Labor force in backyard activities Source: own elaboration with data obtained from applied surveys.

Figure 8 shows the three main destinations of income, with the most important being the purchase of basic foodstuffs $(64.2 \%)$ and, no less important, the resources used to pay for services (17.9\%) and children's education (13.2\%).

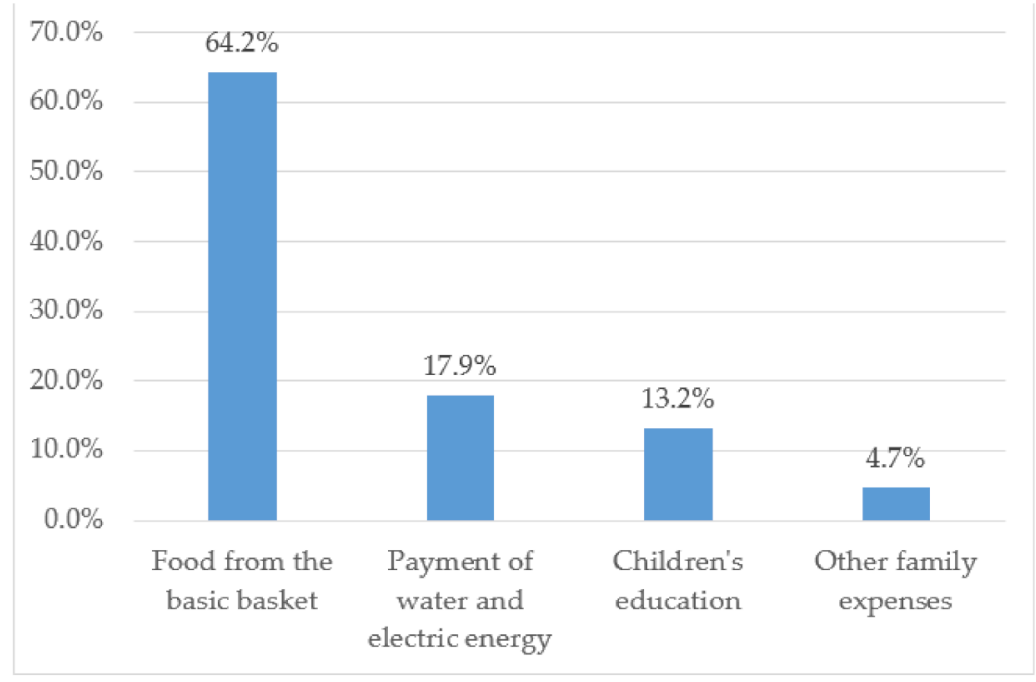

Figure 8. Application of economic benefits of backyard activities. Source: own elaboration with data obtained from the applied surveys.

Likewise, the socioeconomic level to which the families that practice backyard activities belong was determined, and it was found that $44.2 \%$ of the people belong to the $\mathrm{D}+$ level that corresponds to the lower middle class (see Figure 9 and Table 4). At this level, the families own property; they have their minimum sanitary infrastructure covered; and the head of household of these households has, on average, a secondary or primary school education, with income-although not very substantial — that is stable and values that reflect a better quality of life, considering that, in rural communities, the largest population with high levels of poverty and marginalization is concentrated [61]. At this point, it is important to highlight the importance of using and marketing backyard production, 
because this allows families to strengthen their income and considerably improve their socioeconomic conditions.

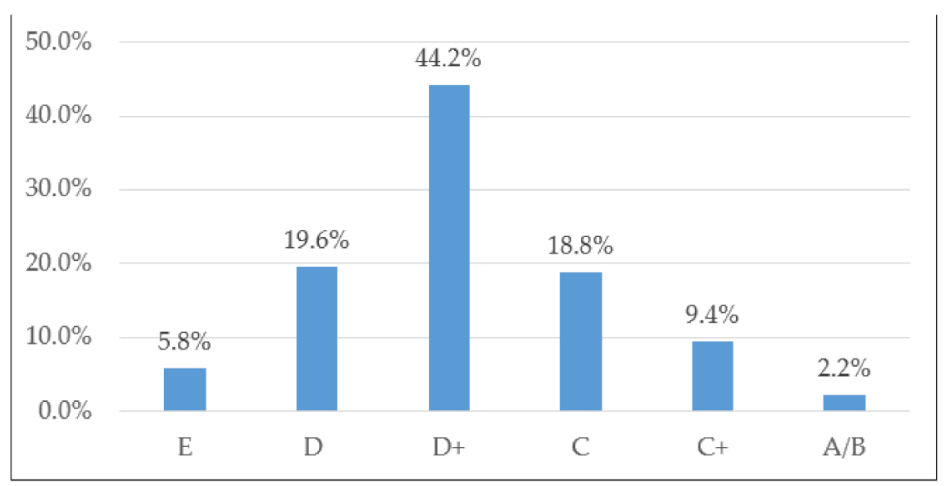

Figure 9. Socioeconomic levels. Source: own elaboration with data obtained from applied surveys.

Finally, regarding production processes, traditional methods predominate in backyard activities, where basic rudimentary tools are used in households without the use of modern technologies, only $9.1 \%$ resort to the use of fertilizers and agrochemicals and $3 \%$ resort to organic products.

Figure 10 shows what the backyard producer answered when questioned about it.

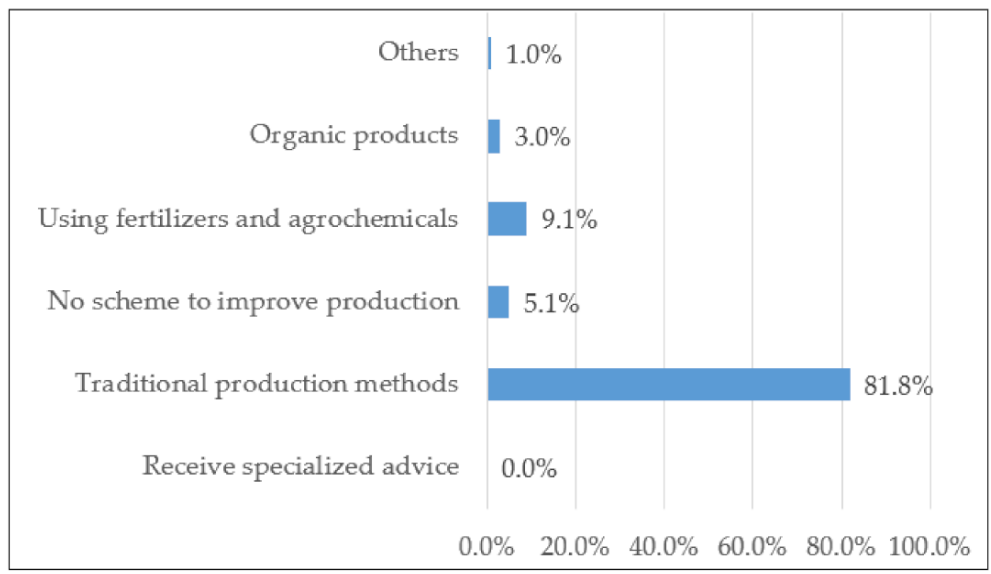

Figure 10. Agricultural practices used in backyard production. Source: own elaboration with data obtained from applied surveys.

\section{Discussion}

If the above data are analyzed from a rural socioeconomic perspective, the importance of backyard activities in any of their different practices contributes basically to the achievement of the development objectives proposed by governments at different levels, in addition to those set forth by international organizations such as the World Bank and the FAO, among others, including the UN Sustainable Development Goals [62], in the purposes related to eradicating poverty and hunger.

These sustainable production schemes, as well as in communities in Europe [8], contribute to food, nutritional and socioeconomic security of rural communities. The forms of production in rural communities in Guasave, as well as in other regions of Africa, are determined by their historical and geographic context [6,7].

Rosas [63] points out that traditional markets do not have the capacity to assign values to natural resources, so more and better rural production systems must emerge, since these are more efficient and generate less impact on the environment. In this sense, the New Rurality approach allows for improving local productive processes and permeates towards 
the consolidation of an economy with a vision towards sustainability, with better results for all. In Australia, the production of urban agriculture per unit area has been quantified, concluding that it can be highly profitable and even supply food for Sydney [64]. In the rural communities of Guasave, it has been found that backyard farming in its agricultural (vegetables and fruit trees) and livestock (various species of poultry and quadrupeds) variants is capable of providing basic food for self-consumption, and even generates surpluses for sale.

Considering the work force of a backyard domestic unit, the effort is reflected in the time dedicated per day to these tasks, as well as the human capital in the care and attention they require. Practically all members of the family participate in backyard activities, i.e., the responsibility does not fall on a single person, since, in a family, the father, mother and children may participate mainly in the backyard activities. It is noteworthy that $60.9 \%$ agree that these tasks require daily attention, especially those related to livestock (see Figure 6), demanding shared responsibilities among the people who make up the family nucleus, which is why these activities are traditionally considered as uses and customs by the inhabitants of rural localities.

The backyard activity in rural communities in Guasave is integrative of the family and is a place of coexistence, as it is in New Zealand family gardens and gardening that is related to identity, connectivity, adaptation, health and well-being of the body, as they are the places conducive to the expression and performance of the family, especially with older adults $[4,5]$.

Considering the economic contributions based on the national minimum wage, the income and/or savings from the consumption and/or commercialization of the production of backyard activities and the socioeconomic level of families in the rural sector of Guasave, these represent an area of opportunity for low-income rural populations to satisfy their basic needs, such as food, payment of services and other important family expenses.

Backyard farming is an important source of income for rural families in Guasave, as expressed by Reference [3], indicating that it represents about $10 \%$ of family income. Reference [11] also considers that backyard activity is a way to improve the quality of life of rural populations. Reference [9] considers that backyard production is an alternative to improve economic income, especially in times of economic crisis, such as the one we are going through because of Covid-19.

\section{Conclusions}

Backyard activities in the rural communities of Guasave are developed in animal raising and agriculture. In other words, there is a variety of backyard activities in the same region. In agricultural activities, home gardens and fruit orchards stand out; animal husbandry includes poultry, pigs, sheep and cows, among other species. The variety of backyard activities in Guasave is an expression of diversity, complementarity and sustainability, since manure is used in agricultural activities, showing that it is possible to combine both activities under a family integration scheme.

It has been possible to estimate the commercialization of products, representing on average $83 \%$ of the minimum wage of a day laborer head of household in the region in the case of animal husbandry activities and $45 \%$ in agricultural activities. This does not take into account the savings in self-consumption, which were not quantified in this study. In addition to the quantifiable, there is the non-quantifiable in monetary terms, such as the space for coexistence and family integration represented by backyard activities.

The results obtained are an input for decision-makers to guide public policies that support the sustainable management of backyard activities, encouraging the marketing of certified organic products and good practices in the production of healthy food for self-consumption.

The combined practices of agriculture and animal husbandry that are predominant in Guasave are different from other forms of production in other latitudes, where one or 
the other predominates; in this case, this is an experience that shows that both activities can coexist.

For the families that carry out backyard activities, knowing that other fellow citizens in the region also practice them is an incentive for them to continue with these activities, since it proves their goodness and generates a sense of belonging and community, by knowing that they are not alone or isolated.

The proper functioning of backyard activities in rural areas is of great importance to achieve a fairer economy for the rural population. The creation of vegetable gardens and/or farms in the backyards of homes is an opportunity to generate a direct interaction between man and the environment, beginning to incorporate, above all, sustainable processes, where, in addition to preserving the diversity of the natural environment, both will benefit from economic and social development, in addition to contributing to food security.

When promoting backyard activities as a strategy to seek food security for rural people, culture, traditional production techniques and the availability of natural resources must be taken into account, as these help strengthen the regional economy; considering that backyard activities represent a key sector to produce healthy food, free of chemicals, developed under artisanal techniques, it allows the rural population to rethink their economic strategies and assess the production options available.

The globalization of markets represents a challenge for the approach of the new rurality; therefore, improving conditions and production patterns constitutes a route for local governments, where problems, in economic terms, may increase-something that would bring social movements and a more acute social rupture; therefore, backyard activities will be the watershed towards the search for improvement in the economy. Thus, backyard practices can influence the quality of life of families and contribute to food sufficiency.

Author Contributions: Conceptualization, V.M.-P.G., H.J.P.-G. and A.A.C.-B.; methodology and software, V.M.-P.G. and H.J.P.-G.; validation, A.A.C.-B. and J.H.-B. and J.d.J.L.-L.; writing-original draft preparation, G.K.G.-F.; data management, N.G.Z.-E. All authors have read and agreed to the published version of the manuscript.

Funding: This research received no external funding.

Institutional Review Board Statement: Not applicable.

Informed Consent Statement: Not applicable.

Data Availability Statement: Not applicable.

Conflicts of Interest: The authors declare no conflict of interest.

\section{References}

1. FAO; IFAD. Decenio de las Naciones Unidas para la Agricultura Familiar 2019-2028; FAO: Roma, Italy, 2019.

2. Rodríguez, J.; Díaz, R.; Gallardo, M.; García, G.A.; Parra, A. El Huerto: Una Alternativa de Producción Familiar; Serie D No.7; INIA: Maracay, Venezuela, 2006.

3. Jaramillo-Villanueva, J.L.; Morales-Jiménez, J.; Domínguez-Torres, V. Importancia económica del traspatio y su relación con la seguridad alimentaria en comunidades de alta marginación en Puebla, México. Agroproductividad 2017, 10, 27-32. Available online: http:/ / search.ebscohost.com/login.aspx?direct=true\&db=fap\&AN=124579832\&site=ehost-live (accessed on 10 February 2021).

4. Wiles, J.; Miskelly, P.; Stewart, O.; Rolleston, A.; Gott, M.; Kerse, N. Gardens as resources in advanced age in aotearoa NZ: More than therapeutic. Soc. Sci. Med. 2020, 113232. [CrossRef] [PubMed]

5. Donati, K. 'Herding is his favourite thing in the world': Convivial world-making on a multispecies farm. J. Rural. Stud. 2019, 66, 119-129. [CrossRef]

6. Bellwood-Howard, I.; Shakya, M.; Korbeogo, G.; Schlesinger, J. The role of backyard farms in two West African urban landscapes. Landsc. Urban Plan. 2018, 170, 34-47. [CrossRef]

7. Bolang, P.D.; Osumanu, I.K. Formal sector workers' participation in urban agriculture in Ghana: Perspectives from the Wa Municipality. Heliyon 2019, 5, e02230. [CrossRef]

8. Galli, F.; Grando, S.; Adamsone-Fiskovica, A.; Bjørkhaug, H.; Czekaj, M.; Duckett, D.G.; Almaas, H.; Karanikolas, P.; MorenoPérez, O.M.; Ortiz-Miranda, D.; et al. How do small farms contribute to food and nutrition security? Linking European small farms, strategies and outcomes in territorial food systems. Glob. Food Secur. 2020, 26, 100427. [CrossRef] 
9. Burgin, S. 'Back to the future'? Urban backyards and food self-sufficiency. Land Use Policy 2018, 78, 29-35. [CrossRef]

10. Jiménez, A.N.A.; Magaña, M.; Ángel, M.; Uc, L.C.C. Factores socioeconómicos asociados a la diversidad pecuaria del traspatio en comunidades mayas de Yucatán y Campeche. BIOtecnia 2019, 21, 5-12. [CrossRef]

11. Chaiban, C.; Robinson, T.P.; Fèvre, E.M.; Ogola, J.; Akoko, J.; Gilbert, M.; Vanwambeke, S.O. Vanwambeke, Early intensification of backyard poultry systems in the tropics: A case study. Animal 2020, 14, 2387-2396. [CrossRef]

12. Dyer, C. Peasants and poultry in England, 1250-1540. Quat. Int. 2020, 543, 113-118. [CrossRef]

13. Deguines, N.; Princé, K.; Prévot, A.-C.; Fontaine, B. Assessing the emergence of pro-biodiversity practices in citizen scientists of a backyard butterfly survey. Sci. Total Environ. 2020, 716, 136842. [CrossRef] [PubMed]

14. Ortiz, F.G.; Magaña, A.P.; Fletes, I.O.; Sánchez, J.P.; Peñaloza, P.D. Contribuciones de la producción en traspatio a los grupos domésticos campesinos. Contrib. Prod. Traspatio Los Grup. Domest. Campesinos 2014, 22, 146-170.

15. Casanova, L.; Martínez, J.; López, S.; López, G. De von Bertalanffy a Luhmann: Deconstrucción del concepto "agroecosistema" a través de las generaciones sistémicas. Rev. Mad. 2016. [CrossRef]

16. Mujíca, E.; Rueda, J.L. La Sostenibilidad de los Sistemas de Producción Campesina en los Andes, 1st ed.; CONDESAN: Lima, Peru, 2017.

17. Landon Lane, C. Los Medios de vida Crecen en los Huertos. 2005. Available online: Ftp://ftp.fao.org/docrep/fao/008/y5112s/ y5112s00.pdf (accessed on 18 February 2021).

18. Portillo-Salgado, I.; Vázquez-Martínez, R. Género y Seguridad Alimentaria: Role Importancia de la Mujer en la Avicultura de Traspatio en Tetela de Ocampo; Universidad Tecnológica de la Mixteca: Puebla, Mexico, 2019.

19. López-González, J.L.; Damián-Huato, M.Á.; Álvarez-Gaxiola, F.; Zuluaga-Sánchez, P.; Parra-Inzunza, F.; Alberto, J.; Ximhai, R.; Zuluaga-Sánchez, P.; Parra-Inzunza, F.; Paredes-Sánchez, J.A. El traspatio de los productores de maíz: En san Nicolás de los ranchos, Puebla-México. Ra Ximhai 2013, 9, 181-198. [CrossRef]

20. Gobierno de México, Agricultura de Traspatio, producción agrícola en beneficio de comunidades marginadas. In Agric. Traspatio Prod. Agric. Benef. Comunidades Marginadas; 2017; p. 1. Available online: https:/ /www.gob.mx/firco/es/articulos/agricultura-detraspatio-produccion-agricola-en-beneficio-de-comunidades-marginadas?idiom=es (accessed on 29 November 2020).

21. Montagut, X.; Dogliotti, F. Alimentos Globalizados Soberanía Alimentaria y Comercio Justo, 2006th ed.; ICARIA, Editorial: Barcelona, España, 2006.

22. Cariño Ibarra, E.; Ocampo Fletes, I.; López Tecpoyotl, Z.G.; Pérez Avilés, R. La construcción territorial de la seguridad alimentaria en comunidades de la mixteca poblana. In México Rural Ante Los Retos Del Siglo XXI Del Siglo XXI, 1st ed.; AMER: Ciudad de México, Mexico, 2017; pp. 1-131.

23. Oliver, L.G.; Santos, A.T. La política de desarrollo rural en México. Existe correspondencia entre lo formal y lo real? Econ. UNAM 2017, 14, 93-117. [CrossRef]

24. Rauch, T. New ruralities in the context of global economic and environmental change-Are small-scale farmers bound to disappear? Geogr. Helv. 2014, 69, 227-237. [CrossRef]

25. Echeverri, R.; Ribero, M.P. Nueva Ruralidad: Visión del Territorio en América Latina y el Caribe, Cargraphics. 2002. Available online: http:/ / www.cusur.udg.mx/fodepal/ArticulosreferentesdeDesSusr/Construyendoeldesarrollorural_archivos_ArturoSC/ Nueva_ruralidad.pdf (accessed on 15 February 2021).

26. Palafox-Muñoz, A.; Martinez-Perezchica, M.G. Turismo y nueva ruralidad: Camino a la sustentabilidad social Tourism and new rurality: On the road to social sustainability. Let. Verdes Rev. Latinoam. Estud. Socioambient. 2015, 137-158. [CrossRef]

27. Segrelles Serrano, J.A.; Vásquez Sánchez, J.; Canales Martínez, G.; Santana Rodríguez, L.M.; Segrelles Serrano, J.A.; Tormo i Santonja, J.; Vera Muñoz, M.I.; Espinoza López, R. Multifuncionalidad Rural y Nueva Ruralidad. La Experiencia Europea y la Potencialidad de Colombia, CLACSO, Madrid, España. 2012. Available online: http://biblioteca.clacso.edu.ar/Espana/giecryal/ 20161220033253/pdf_1100.pdf (accessed on 15 February 2021).

28. Jarquín Sánchez, N.H.; Castellanos Suárez, J.A.; Sangerman-Jarquín, D.M. Pluriactividad y agricultura familiar: Retos del desarrollo rural en México. Rev. Mex. Cienc. Agric. 2017, 8, 949-963. [CrossRef]

29. Ortega-cerdà, M.; Rivera-ferre, M.G. Indicadores internacionales de Soberanía Alimentaria. Nuevas herramientas para una nueva agricultura. Revibec. Rev. Iberoam. Econ. Ecol. 2010, 14, 53-77.

30. Duché-García, T.T.A.; Bernal-Mendoza, H.; Ocampo-Fletes, I.; Juárez-Ramón, D.; Villarreal-Espino Barros, Ó.A. Agricultura de traspatio y agroecología en el proyecto estratégico de seguridad alimentaria (PESA-FAO) del Estado de Puebla. Agric. Soc. Desarro. 2017, 14, 263. [CrossRef]

31. López-Moreno, I. La nueva ruralidad y la nueva gobernanza en México: Una propuesta de categorización territorial operativa para los nuevos territorios rurales. Sociológica 2017, 32, 217-239. Available online: http:/ / www.redalyc.org/articulo.oa?id=3050 52771007 (accessed on 15 February 2021).

32. Calva, J.L. Los Campesinos y su Devenir en las Economías de Mercado; Siglo XXI Editores: Mexico City, Mexico, 1988.

33. Sánchez, J.M.P.; Orozco, J.J.V.; Montes, L.R. Estudios sobre agricultura y conocimiento tradicional en México, Repos. Inst. La Univ. Autónoma Del Estado México. 2014, pp. 144-156. Available online: http://ri.uaemex.mx/bitstream/handle/20.500.11799/32863 /ArtículorevistaJapónencoautoriaJ.ManuelJ.JesúsyLauraR.2015.pdf?sequence=1\&isAllowed=y (accessed on 2 April 2019).

34. Romero-Arenas, O.; Damián-Huato, M.Á.; Cruz-León, A.; Sangerman-Jarquín, D.M.; López-Reyes, L.; Carcaño-Montiel, M. Modelo productor-innovador y autosuficiencia alimentaria para milperos de secano: Propuesta de política pública sostenible. Scr. Nov. 2019, 23. [CrossRef] 
35. Cedillo, J.G.G.; Gómez, L.I.A.; Esquivel, C.E.G. Agroecología y sustentabilidad. Converg. Rev. Cienc. Soc. 2008, 15, 51-87. Available online: http:/ / www.redalyc.org/articulo.oa?id=10504604 (accessed on 15 February 2021).

36. Roulet, S. La Importancia de la Ganadería en Los Sistemas Agroecológicos, Voces y Ecos. (n.d.) 38. Available online: https: //inta.gob.ar/sites/default/files/vye38_9_la_importancia_de_la_ganaderia_en_los_sistemas_agroecologicos.pdf (accessed on 15 February 2021).

37. FAO. Desarrollo Positivo de la Agroecología en México. 2012. Available online: http://www.fao.org/in-action/agronoticias/ detail/es/c/509187/ (accessed on 12 October 2019).

38. Alianza Salud, Elige FAO a México para Impulsar Agroecología y Erradicar el Hambre. 2019. Available online: https:/ /alianzasalud.org.mx/2019/04/elige-fao-a-mexico-para-impulsar-agroecologia-y-erradicar-el-hambre/ (accessed on 12 October 2019).

39. Gavito, M.E.; Van Der Wal, H.; Aldasoro, E.M.; Ayala-Orozco, B.; Bullén, A.A.; Cach-Pérez, M.; Casas-Fernández, A.; Fuentes, A.; González-Esquivel, C.; Jaramillo-López, P.; et al. Ecología, tecnología e innovación para la sustentabilidad: Retos y perspectivas en México. Rev. Mex. Biodivers. 2017, 88, 150-160. [CrossRef]

40. Uribe, M.C.Á.; López, L.P.M.; Torres, J.E.C. Caracterización socioeconómica y seguridad alimentaria de los hogares productores de alimentos para el autoconsumo, Antioquia-Colombia. Agroalimentaria 2007, 12, 109-122.

41. Martínez Salvador, L. Seguridad alimentaria, autosuficiencia y disponibilidad del amaranto en México. Probl. Desarro. 2016, 47, 107-132. [CrossRef]

42. Rodríguez-Peñuelas, M.A. Diseño de Proyectos y Desarrollo de Tesis en Ciencias Administrativas, Organizacionales y Sociales, 1st ed.; UAS: Culiacan, Mexico, 2010.

43. Hernández-Sampieri, R.; Fernandez-Collado, C.; Baptista-Lucio, P. Metodología de la Investigación, 6th ed.; McGrawHill: Mexico City, Mexico, 2014.

44. INEGI. Anuario estadístico y geográfico de Sinaloa 2017. Inst. Nac. Estad. Geogr. 2017, 475, 1.

45. INEGI. Prontuario de Información Geográfica Municipal, Inegi. 2009, p. 7. Available online: http://www3.inegi.org.mx/ contenidos/app/mexicocifras/datos_geograficos/28/28034.pdf (accessed on 15 February 2021).

46. INEGI. Censo de población y vivienda 2010, Censos y Conteos Población y Vivienda. 2010, p. 1. Available online: https: / / www.inegi.org.mx/programas /ccpv/2010/?ps=microdatos (accessed on 10 March 2021).

47. SEDATU. Atlas de Riesgos Naturales del Municipio de Guasave, 2014; SEDATU: Mexico City, Mexico, 2014.

48. CONAGUA. CONAGUA/Acuíferos Sinaloa. 2018; p. 1. Available online: https://sigagis.conagua.gob.mx/gas1/sections/Edos/ sinaloa/sinaloa.html (accessed on 20 February 2021).

49. Ayuntamiento de Guasave, H. Información de Guasave. 2020. Available online: http://guasave.gob.mx/s/informacion-deguasave/ (accessed on 20 February 2021).

50. INEGI. Sala de Prensa, En Sinaloa Somos 3026943 Habitantes Censo Población y Vivienda 2020. Sinaloa. 2021, p. 1. Available online: https:/ / www.inegi.org.mx/app/saladeprensa/noticia.html?id=6261 (accessed on 16 February 2021).

51. CONEVAL. Informe Anual Sobre La Situación de Pobreza y Rezago Social Guasave, Sinaloa Informe Anual Sobre La Situación de Pobreza y Rezago Social Guasave, Sinaloa III. Indicadores asociados al índice de. 2010. Available online: https://www.gob.mx/ cms/uploads/attachment/file/46353/Sinaloa_011.pdf (accessed on 16 February 2021).

52. INEGI. Población, Población. 2020, p. 1. Available online: https://www.inegi.org.mx/temas/estructura/ (accessed on 3 February 2021).

53. Malhotra, N.K. Investigación de Mercados, 5th ed.; Pearson: Mexico City, Mexico, 2008.

54. Torres, M.; Paz, K.; Salazar, F. Métodos de Recolección de Datos Para una Investigación; Universidad Rafael Landívar: Guatemala City, Guatemala, 2006.

55. Salinas-peba, L.; Magaña-Magaña, M.Á. Aportaciones de la milpa y traspatio a la autosuficencia aliemntaria en comunidades mayas de Yucatán. Estud. Soc. 2016, 24, 182-203.

56. Vera, O.; Vera, F. Evaluación del nivel socioeconómico: Presentación de una escala adaptada en una población de Lambayeque. Rev. Cuerpo Méd. 2013, 6, 41.

57. López-Romo, H. Nuevo Índice de Nivel Socioeconómico AMAI. 2008. Available online: http://www.amai.org/congreso/2008 /memorias/ponencias/lopezromo.pdf (accessed on 16 February 2021).

58. INEGI. Número de Habitantes de Sinaloa. 2015, p. 1. Available online: http://cuentame.inegi.org.mx/monografias/informacion/ sin/poblacion/ (accessed on 25 October 2019).

59. Díaz Narváez, V.P. Metodología de la Investigación Científica y Bioestadística para Profesionales y Estudiantes de Ciencias de la Salud, 1st ed.; Universidad Finis Terrae: Santiago, Chile, 2009.

60. INEGI. Estadísticas a Propósito del día del Trabajador Agrícola. 2016; pp. 1-18. Available online: http://www.diputados. gob.mx/sedia/biblio/usieg/comunicados/25ene19/economia/18_diadeltrabajadoragricola_230118-18.pdf (accessed on 16 February 2021).

61. DOF. Programa Nacional de Protección a los Derechos del Consumidor 2013-2018. Acuerdo Por El Que Se Aprueba El Programa Nac. Protección a Los Derechos Del Consum. 2013-2018. 2014; pp. 1-15. Available online: http://dof.gob.mx/nota_detalle.php? codigo $=5343849 \&$ fecha $=08 / 05 / 2014$ (accessed on 10 March 2021).

62. CEPAL. La Agenda 2030 y los Objetivos de Desarrollo Sostenible: Una Oportunidad para América Latina y el Caribe; Objetivos, Metas e Indicadores Mundiales: Santiago, Chile, 2019. 
63. Rosas-Baños, M. New Rurality from two visions of rural development and sustainability: Environmental Economics and Ecological Economics. Inst. Politéc. Nac. CIIDIR Unidad Oaxaca 2013, 12, 225-241. Available online: http://www.scielo.cl/pdf/ polis/v12n34/art12.pdf (accessed on 16 February 2021).

64. Mcdougall, R.; Rader, R.; Kristiansen, P. Urban agriculture could provide 15\% of food supply to Sydney, Australia, under expanded land use scenarios. Land Use Policy 2020, 94, 104554. [CrossRef] 